\title{
Analysis of Public Awareness Level of the Community- Based Total Sanitation Program (STBM) (Case Study of Residents in Potrobangsan Village, North Magelang, Magelang City)
}

\author{
Tri Asih Wismaningtyas ${ }^{1}$, Yuni Kurniasih ${ }^{2}$, Fitria Khairum Nisa ${ }^{3}$ \\ \{triasihwismaningtyas@untidar.ac.id ${ }^{1}$, yunikurniasih@untidar.ac.id ${ }^{2}$, fitriaknisa@untidar.ac.id ${ }^{3}$ \} \\ Faculty of Social and Political Science, Universitas Tidar, Magelang, Indonesia ${ }^{1}$ \\ Faculty of Social and Political Science, Universitas Tidar, Magelang, Indonesia ${ }^{2}$ \\ Faculty of Social and Political Science, Universitas Tidar, Magelang, Indonesia ${ }^{3}$
}

\begin{abstract}
The government organized a Community Based Total Sanitation Program (STBM) to change people's hygiene behavior. However, the awareness to create a sanitation system according to Clean and Healthy Living Standards and Behaviors is still low. Therefore, this research aims to see the awareness level of STBM program and factors that influence it. This research uses quantitative method through survey and qualitative method through interview. The results of this study indicate that the highest level of awareness on the five STBM pillars is at attitude level where the community supports the STBM program. Pillar 1: Stop Open Defecation by $88.07 \%$, pillar 2: Washing Hands with Soap by $87.16 \%$, pillar 3: Drinking Water and Household Food Management by $76.25 \%$, pillar 4: Securing Household Waste by $61.70 \%$ and pillar 5: Safeguarding Home Liquid Waste Stairs by $62.06 \%$. Meanwhile, the factors that influence them are knowledge, socioeconomic level, government commitment and program monitoring.
\end{abstract}

Keywords: Awareness, Sanitation, STB 


\section{Introduction}

Population of Magelang City increases every year, both due to birth and immigration from people from other city to meet their needs, such as education to work. The more people in Magelang City, the higher need for housing. Currently, infrastructure development is intensively carried out in order to meet community needs for housing needs, one of them is sanitation

Sanitation is a condition related to public health, especially the provision of clean drinking water and adequate waste disposal [12]. Sanitation can help prevent disease by controlling the physical environmental factors that are associated with the chain of disease transmission. Sanitation relates to human waste disposal facilities and services, as well as the maintenance of hygienic conditions through waste and liquid waste management.

The Government of Magelang City encourage the realization of an environmental and sanitation development program with a $100-0-100$ pattern. This pattern means $100 \%$ access to clean water, $0 \%$ slum areas, and $100 \%$ access to sanitation. Magelang City Government is also collaborating with domestic and foreign companies in various sectors and all community to manifest the 100-0-100 pattern, especially since this program has actually been contained in the RPMJD 2016-2021 [11]. However, manifesting the 100-0-100 pattern, will not match expectations without community participation.

The Government of Magelang City is committed to make improper sanitation reach $0 \%$ by 2018. However, data in 2018 shows that 1,653 households in Magelang City still do not have proper sanitation [13]. Some factors that cause the inadequate sanitation are lack of public awareness, bad habit like defecating in rivers, education and social economy.

The Government of Magelang City has continued to increase the public awareness to build a good sanitation system in order to create a clean and healthy lifestyle. The activity is part of the Indonesia Urban Water Sanitation Program and Hygiene-Environmental Health Program for All (IUWASH) Plus Central Java Region. Indonesia, the United States, and Switzerland build cooperation in the form of the IUWASH Plus Program. The Regional Drinking Water Company (PDAM) of Magelang City is one of the seven PDAMs that have received support from the United States Agency for International Development (USAID) and The Swiss State Secretariat for Economic Affairs (SECO) through the IUWASH PLUS Program for the 2019-2021 period [10]..

IUWASH Plus Central Java Regional Manager, Jefry Budiman mentioned that Magelang City is one of the high populated cities which is the target of implementing LSIC (Local Sustainability and Innovation Component), a program that provides opportunities for the community to overcome the challenges of implementing various drinking water, sanitation and hygienic behavior programs that fair and equal. He mentioned that the construction of the SPALD (Domestic Wastewater Management System) is a form of the IUWASH work program that has been carried out in several urban villages in Magelang City. 3 out of 17 sub-districts in Magelang City have built 20 SPALD units with 160 house connections, while the funds for SPALDS construction are Rp734 million [9]. The program runs in two stages, the first stage in 2011 called IUWAH and the second stage in 2019 called IUWASH Plus.

Magelang City assesses that there is a need to increase public awareness in building a good sanitation system. This is because not all residents have the awareness to create a sanitation system according to standards and hygiene and healthy living habits (PHBS). Therefore, the 
government continues to increase public awareness by conducting socialization and triggering so that people increase awareness not to defecate in any place. In order to improve the public awareness, the Government of Magelang City conduct waste water management education targeting every urban village.

The main problem that will be faced to increase public awareness is how to give enthusiasm and encouragement to the community to participate considering that each region has its own culture (Sarvarzad eh \& Abidin, 2012). The existence of a facilitator is very important to support community participation and awareness, such as providing motivation and good explanations to the community.

In the topic of community-based sanitation, several previous studies have been conducted. In 2013, Bagus Danar Andito, Ari Subowo, Dewi Rostyaningsih conducted a study entitled Evaluation of the Implementation of Community Based Drinking Water and Sanitation (Pamsimas) Provision Programs in Karangrayung District, Regency. This research shows that the program is quite effective even though it encountered several obstacles such as the weak economic condition of the community and limited supporting facilities. Next, a study conducted by Agus Erwin Ashari and Fajar Akbar in 2015 entitled Evaluation of Community-Based Total Sanitation Programs in Mamuju District. As a result, there are several indicators of adequate input components in the form of policies, authorities and responsibilities, human resources but not for operations and infrastructure. The process of component planning, organization and reporting is adequate, but implementation and monitoring indicators are inadequate. This has an impact on all output components that have not reached the set standards. From these studies it is known that there are still obstacles faced by government programs in the sanitation sector.

Based on the description above, focus of this research on the level of community awareness of the Community-Based Total Sanitation (STBM) program in Potrobangsan Village, North Magelang, Magelang City. The reason for choosing the research locus because Potrobangsan was one of the sub-districts that had not declared itself to be an ODP partner (free from littering). Therefore, this research aims to see the awareness level of STBM program and factors that influence it.

\subsection{Literatur Review}

\section{Awareness}

Awareness is an individual's ability to make contact with his environment as well as with himself (through his five senses) and impose restrictions on his environment and on himself (through attention). This awareness is indicated by the individual being aware of themselves and their environment so that their memory, attention and orientation includes space, time and people in good condition.

According to Soekanto (1982) awareness has four indicators which are stages that refer to the level of awareness[7]:

1. Knowledge; someone's knowledge regarding certain behavior. Like what can and should not be done.

2. Understanding; amount of information that a person has about the content of the behavior. Such as goals, benefits and so on.

3. Attitude; tendency to accept or reject certain behavior.

4. Pattern of behavior (action); about whether or not a behavior is valid in society. If applicable, the extent to which they apply and to what extent society complies with them. 


\section{Health Policy}

According to Walt (1994 in Ayunigtyas, 2014) health policy includes various efforts and decision-making actions consisting of technical aspects of medical and health services as well as involvement of actors at the scale of individuals, organizations and government institutions, the private sector, NGOs and other community representative impact on health[1].

The elements that determine the quality of a health policy according to the World Health Organization (WHO) are as follows:

a. Holistic approach; health policy does not only rely on curative efforts but must also consider preventive, promotive and rehabilitative efforts.

b. Participatory; community participation will improve the quality of policies. Community power is the driving force in implementing policies and solving problems.

c. Healty public policy; every policy must be directed to support the creation of conducive and community-oriented health development.

d. Equity; policies must be evenly distributed from health services.

e. Efficiency; health services must be proactively oriented by optimizing costs and technology.

f. Quality; the government must provide quality health services. In facing global competition, the quality of health services must be pursued at an international standard.

g. Community empowerment; this empowerment is carried out by optimizing social capital in society.

h. Self-reliant; strived for health policy to fulfill public confidence in the capacity of health services itself.

Based on the health policy elements above, it is clear that the principles of participatory and community empowerment increasingly emphasize the urgency of community involvement. One of the health program that encourages participatory aspects is Community Based Total Sanitation (STBM).

\section{Community-Based of Total Sanitation}

Community-Based Total Sanitation (STBM) is an approach to change hygiene and sanitation behavior through community empowerment using the triggering method (www.stbm.kemkes.go.id, no year). The STBM program has outcome and output indicators. The STBM outcome indicator is a reduced incidence of diarrhea and other environment-based diseases related to sanitation and behavior. While the STBM output indicators are as follows:

a. Every individual and community have access to basic sanitation facilities so that they can create a community that is free from defecating in any place.

b. Each household has implemented safe drinking water and food management in the household.

c. Every household and public service facilities in a community (such as schools, offices, restaurants, health centers, markets, terminals) have hand washing facilities (water, soap, etc), so everyone can wash their hands properly.

d. Every household manages their waste properly.

e. Every household manages their trash properly. 
Based on Permenkes Number 3 of 2014 concerning Community Based Total Sanitation to manifest the program objectives, there are five pillars of Community Based Total Sanitation (STBM) which consist of:

1. Pillar 1: Stop Open Defecation (SBS)

A condition when every individual in the community does not defecate in the open area. The SBS behavior is followed by the use of sanitary facilities in the form of healthy toilet.

2. Pillar 2: Washing Hands with Soap (CTPS)

CTPS is the behavior of washing hands using soap and clean running water.

3. Pillar 3: Drinking Water and Household Food Management (PAMM-RT)

PAMM-RT is a process of processing, storing and utilizing safe drinking water and food management in households.

4. Pillar 4: Household Waste Protection

The purpose of household waste protection is to avoid storing garbage in the house by immediately handling garbage. Safe waste protection is the collection, transportation, processing, recycling or disposal of waste material in a manner that does not endanger public health and the environment.

5. Pillar 5: Safeguarding Household Liquid Waste

The process of safeguarding liquid waste that is safe at the household level to avoid stagnant wastewater that has the potential to cause environmental-based diseases.

\section{$2 \quad$ Methodology}

This study uses a mixed method between quantitative methods and qualitative methods. The description of the level of public awareness of Community Based Total Sanitation is obtained by quantitative methods and to deepen the discussion, the factors that influence it are explored using qualitative methods. The aim to get a comprehensive and in-depth picture of the community awareness of Potrobangsan Village, Magelang City in the Community-Based Total Sanitation program (STBM).

Respondents of this study were the heads of families in Potrobangsan Village, Magelang City, there are 8,114 heads of families. Based on calculations using the Slovin formula with a degree of error of $10 \%$, the number of samples taken are 99 respondents comes from representatives of each region in Potrobangsan Village. The probability sampling technique that will be used is cluster sampling because the sample size is divided into several community units (RW) so that each RW is represented using this technique.

Quantitatively, researchers conducted a survey by providing a questionnaire. Meanwhile, qualitatively, researchers conducted interviews with respondents to explain in more detail the results of the questionnaire and interviews with the local head of the region. The data analysis technique used in this research is univariate analysis which produces a frequency distribution and percentage of each variable in STMB. 


\section{$3 \quad$ Finding and Discussion}

Analysis of Public Awareness of the Community-Based Total Satination Program (STBM) in Potrobangsan

Pillar 1: Stop Open Defecation (SBS)

This pillar encourages every individual in society not to defecate in the open areas. The SBS behavior is followed by the use of good sanitation facilities, namely healthy toilet.

Table 1. Achievement Data of Pillar 1 of Potrobangsan Village Community in 2020

\begin{tabular}{|c|c|c|c|c|c|}
\hline $\begin{array}{c}\text { Awareness } \\
\text { Level }\end{array}$ & $\begin{array}{l}\text { Very } \\
\text { Inappr } \\
\text { opriate }\end{array}$ & $\begin{array}{c}\text { Inappr } \\
\text { opriat } \\
\text { e }\end{array}$ & $\begin{array}{c}\text { Appro } \\
\text { priate } \\
\text { Enoug } \\
\mathrm{h}\end{array}$ & $\begin{array}{l}\text { Appro } \\
\text { priate }\end{array}$ & $\begin{array}{l}\text { Very } \\
\text { Appro } \\
\text { priate }\end{array}$ \\
\hline \multirow[t]{2}{*}{ Knowledge } & 34.86 & & & 10.09 & 52.29 \\
\hline & $\%$ & $0.00 \%$ & $2.75 \%$ & $\%$ & $\%$ \\
\hline \multirow{3}{*}{$\begin{array}{l}\text { Understandi } \\
\text { ng } \\
\text { Attitude }\end{array}$} & 27.52 & & & 17.43 & 48.62 \\
\hline & $\%$ & $0.92 \%$ & $5.50 \%$ & & \\
\hline & & & & 10.40 & 88.07 \\
\hline \multirow{3}{*}{ Behavior } & $0.00 \%$ & $0.31 \%$ & $1.22 \%$ & $\%$ & \\
\hline & 29.70 & & & & 56.31 \\
\hline & $\%$ & $3.44 \%$ & $2.75 \%$ & $7.80 \%$ & $\%$ \\
\hline
\end{tabular}

Source: Primary data is processed, 2020

Based on data obtained from the field, people of Potrobangsan Village are mostly aware of the the government appeal of Stop Open Defecation (SBS). There are $52.29 \%$ of respondents that very aware of the program. However, there still $34.86 \%$ of respondents that did not know the Open Defecation Stop program (SBS). For the level of understanding, there are $48.62 \%$ of the respondents knew the benefits of the Open Defecation Stop (SBS) appeal. Then, from the respondent's attitude, the attitude score was classified as very good, $88.07 \%$ of the respondents agreed not to defecate openly, not defecating in rivers and agreed to have a toilet at home. Furthermore, in terms of behavior, more than half of the respondents, $56.31 \%$, are very in accordance with the criteria for the Open Defecation Stop Program (SBS), which are having a toilet at home, there is a public toilet in the neighborhood, daily defecating in household or public toilet, do not defecate in rivers / streams everyday. Therefore, the achievement of the pillar 1 has a good category in knowledge, understanding and behavior while for attitude it is already in the very good category.

Pillar 2: Washing Hands with Soap (CTPS)

This pillar encourages every individual in the community to have the behavior of washing hands using soap and clean running water. The following is the field survey data related to the achievements of the Hand Washing with Soap (CTPS) pillar for the people of Potrobangsan Village. 
Table 2. Achievement Data of Pillar 2 of Potrobangsan Village Community in 2020

\begin{tabular}{|c|c|c|c|c|c|}
\hline $\begin{array}{c}\text { Awareness } \\
\text { Level }\end{array}$ & $\begin{array}{c}\text { Very } \\
\text { Inappr } \\
\text { opriat } \\
\mathrm{e} \\
\end{array}$ & $\begin{array}{c}\text { Inappr } \\
\text { opriat } \\
\text { e }\end{array}$ & $\begin{array}{c}\text { Appro } \\
\text { priate } \\
\text { Enoug } \\
\mathrm{h}\end{array}$ & $\begin{array}{l}\text { Appro } \\
\text { priate }\end{array}$ & $\begin{array}{c}\text { Very } \\
\text { Appro } \\
\text { priate }\end{array}$ \\
\hline Knowledge & & & & 12.84 & 85.32 \\
\hline & $0.00 \%$ & $0.00 \%$ & $1.83 \%$ & $\%$ & $\%$ \\
\hline Understandi & & & 12.04 & 18.69 & 63.30 \\
\hline $\begin{array}{l}\text { ng } \\
\text { Attitude }\end{array}$ & $4.59 \%$ & $1.38 \%$ & $\%$ & $\begin{array}{l}\% \\
11.01\end{array}$ & $\begin{array}{l}\% \\
87.16\end{array}$ \\
\hline \multirow{3}{*}{ Behavior } & $0.00 \%$ & $0.00 \%$ & $1.83 \%$ & & $\%$ \\
\hline & & & & 18.81 & 75.92 \\
\hline & $0.00 \%$ & $0.34 \%$ & $4.93 \%$ & $\%$ & $\%$ \\
\hline
\end{tabular}

Based on data obtained from the field, the majority of the Potrobangsan Village community, $85.32 \%$ of the respondents already knew about the call for Hand Washing with Soap (CTPS). There is no community that does not yet know about this appeal. This is also in line with the conditions of the Covid-19 pandemic which encourage people to wash their hands frequently using soap intensively. From the level of understanding, as many as $63.30 \%$ of respondents know the benefits of the handwashing with soap (CTPS) appeal, which consists of understanding seven steps to wash hands properly, time of handwashing properly with soap; before eating, after defecating, before preparing food. Apart from themselves, the respondent also ensures that everyone who lives in his house understands all of the criteria of proper handwashing.

Then seen from the respondent's attitude, the attitude score towards the pillar 2 is classified as very good. $87.16 \%$ of respondents agreed to wash their hands with soap. In terms of behavior, $75.92 \%$, have done handwashing properly with soap. The indicators of this behavior are avaibility of running water house and soap for handwashing in their house, washing hands daily, washing hands in some recommended time; after defecating, before preparing food. The achievement of the Handwashing with Soap (CTPS) pillar was in the very good category for knowledge, understanding and behavior.

\section{Pillar 3: Drinking Water and Household Food Management (PAMM-RT)}

This pillar encourages each individual in the community to familiarize himself with the patterns of processing, storing and utilizing safe drinking water and food management in the household. The following is the field survey data related to the achievement of the pillars of drinking water \& household food (PAMM-RT) for the people of Potrobangsan Village. 
Table 3. Achievement Data of Pillar 3 of Potrobangsan Village Community in 2020

\begin{tabular}{|c|c|c|c|c|c|}
\hline $\begin{array}{c}\text { Awareness } \\
\text { Level }\end{array}$ & $\begin{array}{c}\text { Very } \\
\text { Inappro } \\
\text { priate }\end{array}$ & $\begin{array}{c}\text { Inappr } \\
\text { opriat } \\
\mathrm{e}\end{array}$ & $\begin{array}{c}\text { Appro } \\
\text { priate } \\
\text { Enoug } \\
\mathrm{h}\end{array}$ & $\begin{array}{l}\text { Appro } \\
\text { priate }\end{array}$ & $\begin{array}{l}\text { Very } \\
\text { Appro } \\
\text { priate }\end{array}$ \\
\hline \multirow[t]{2}{*}{ Knowledge } & & & 13.76 & 25.69 & 57.80 \\
\hline & $2.75 \%$ & $0.00 \%$ & $\%$ & & \\
\hline \multirow{4}{*}{$\begin{array}{l}\text { Understandi } \\
\text { ng } \\
\text { Attitude }\end{array}$} & & & & 24.08 & 68.81 \\
\hline & $0.00 \%$ & $0.23 \%$ & $6.88 \%$ & $\%$ & $\%$ \\
\hline & & & & 14.68 & 76.15 \\
\hline & $3.52 \%$ & $0.92 \%$ & $4.74 \%$ & $\%$ & $\%$ \\
\hline Behavior & $12.48 \%$ & $3.12 \%$ & $8.26 \%$ & $\begin{array}{l}11.01 \\
\%\end{array}$ & $\begin{array}{l}65.14 \\
\%\end{array}$ \\
\hline
\end{tabular}

Source: Primary data is processed, 2020

Based on the data above, there are $57.80 \%$ of respondents, already know the benefits of managing household drinking water \& food. Level of respondents understanding, $68.81 \%$ of them understood how to treat water before drinking, how to store processed drinking water, how to care for containers for drinking water and how to store food that was served. Then from the respondent's attitude, the attitude value is very good, $76.15 \%$ of respondents agree to boil water before drinking, filter drinking water before cooking, store water before cooking to settle dirt, store drinking water that has been treated in a tightly closed container, wash drinking water containers regularly for once a week and agree that the food served should be covered. Furthermore, in terms of behavior, $65.14 \%$ of respondents are very in accordance with the criteria of the pillar 3 program. Such as boiling water before drinking, filtering drinking water before cooking, storing water before cooking to settle dirt, storing treated drinking water in a tightly closed container, washing the drinking water container regularly for once a week and agreeing that the food served should be closed. Therefore, the achievement of the pillar of Household Drinking Water and Food Management (PAMM-RT) is in the very good category for knowledge, understanding and behavior.

\section{Pillar 4: Household Waste Protection}

This pillar encourages every individual in society to store garbage in the house to immediately handle waste. The process consists of collecting, transporting, processing, recycling or disposing of the waste material in a manner that does not endanger public health and the environment. The following is the field survey data related to the achievements of the pillars of household waste protection for the Potrobangsan Village community. 
Table 4. Achievement Data of Pillar 4 of Potrobangsan Village Community in 2020

\begin{tabular}{|c|c|c|c|c|c|}
\hline $\begin{array}{c}\text { Awareness } \\
\text { Level }\end{array}$ & $\begin{array}{c}\text { Very } \\
\text { Inappro } \\
\text { priate }\end{array}$ & $\begin{array}{c}\text { Inappr } \\
\text { opriat } \\
\mathrm{e}\end{array}$ & $\begin{array}{c}\text { Appro } \\
\text { priate } \\
\text { Enoug } \\
\text { h }\end{array}$ & $\begin{array}{l}\text { Appro } \\
\text { priate }\end{array}$ & $\begin{array}{l}\text { Very } \\
\text { Appro } \\
\text { priate }\end{array}$ \\
\hline Knowledge & & & & 19.27 & 52.29 \\
\hline & $13.76 \%$ & $7.34 \%$ & $7.34 \%$ & & $\%$ \\
\hline Understandi & & & 11.01 & 19.72 & 39.91 \\
\hline & $22.48 \%$ & $6.88 \%$ & $\%$ & $\%$ & $\%$ \\
\hline Attitude & & & & 16.74 & 61.70 \\
\hline \multirow{3}{*}{ Behavior } & $9.86 \%$ & $5.28 \%$ & $6.42 \%$ & $\%$ & $\%$ \\
\hline & & 10.28 & & & 38.17 \\
\hline & $36.33 \%$ & $\%$ & $7.71 \%$ & $7.52 \%$ & $\%$ \\
\hline
\end{tabular}

Source: Primary data is processed, 2020

Based on these data, the people of Potrobangsan Village, 52.29\% of respondents, already know the appeal for household solid waste management. However, there are $13.76 \%$ of respondents that do not know about the appeal. From the level of understanding, only $39.91 \%$ of respondents know the benefits and ways of managing house solid waste. Although the respondents' understanding only $39.91 \%$, their attitude vallue was quite good, $61.70 \%$ of respondents agreed to the pillar 4 criteria, such as reprocess household solid waste, bury household solid waste, dispose of household solid waste in the trash and process household solid waste into compost. However, in terms of behavior, only $38.17 \%$ of the respondents' that has done the pillar 4 criteria as mentioned.

Furthermore, in terms of behavior, $38.17 \%$ of the respondents' conditions are quite in accordance with the criteria for household solid waste management, namely owning a trash can, disposing of household solid waste in the trash, reprocessing household solid waste, burying household solid waste, disposing of solid waste household waste in the trash and process household solid waste into compost. However, on the other hand, $36.33 \%$ had the opposite attitude, namely not securing their household solid waste. From this it can be seen that the achievement of the Household Waste Protection pillar has a good category for knowledge and understanding, while for attitudes it has reached a very good level. However, it is not in accordance with the behavior which is still in the quite good category and still needs a lot of improvement.

Pillar 5: Safeguarding Household Liquid Waste

This pillar encourages the safeguarding of safe liquid waste at the household level to avoid stagnant wastewater that has the potential to cause environmental-based diseases. The following is the field survey data related to the achievements of the pillar of household liquid waste protection for the Potrobangsan Village community. 
Table 5. Achievement Data of Pillar 5 of Potrobangsan Village Community in 2020

\begin{tabular}{|c|c|c|c|c|c|}
\hline $\begin{array}{c}\text { Awareness } \\
\text { Level }\end{array}$ & $\begin{array}{l}\text { Very } \\
\text { Inappr } \\
\text { opriat } \\
\text { e }\end{array}$ & $\begin{array}{l}\text { Inappr } \\
\text { opriat } \\
\text { e }\end{array}$ & $\begin{array}{c}\text { Appro } \\
\text { priate } \\
\text { Enoug } \\
\text { h }\end{array}$ & $\begin{array}{l}\text { Appro } \\
\text { priate }\end{array}$ & $\begin{array}{l}\text { Very } \\
\text { Appro } \\
\text { priate }\end{array}$ \\
\hline Knowledge & $\begin{array}{l}55.05 \\
\%\end{array}$ & $6.42 \%$ & $\begin{array}{l}12.84 \\
\%\end{array}$ & $\begin{array}{l}10.09 \\
\%\end{array}$ & $\begin{array}{l}15.60 \\
\%\end{array}$ \\
\hline $\begin{array}{l}\text { Understandin } \\
\mathrm{g} \\
\text { Attitude }\end{array}$ & $\begin{array}{l}55.96 \\
\%\end{array}$ & $\begin{array}{l}11.47 \\
\%\end{array}$ & $\begin{array}{l}12.84 \\
\% \\
11.62\end{array}$ & $\begin{array}{l}10.09 \\
\% \\
17.74\end{array}$ & $\begin{array}{l}9.63 \% \\
62.08\end{array}$ \\
\hline Behavior & $\begin{array}{l}6.42 \% \\
11.62 \\
\%\end{array}$ & $2.14 \%$ & $7.95 \%$ & $\begin{array}{l}\% \\
14.68 \\
\%\end{array}$ & $\begin{array}{l}\% \\
59.94 \\
\%\end{array}$ \\
\hline
\end{tabular}

Source: Primary data is processed, 2020

Based on the data obtained from the field, the aspects of community knowledge of Potrobangsan Village on the appeal for household liquid waste protection tend to be low. $55.05 \%$ of respondents do not know the appeal for household liquid waste management. From the level of understanding, as much as $55.96 \%$ of respondents do not know the benefits and ways of managing household liquid waste. However, the respondent's attitude shows $62.08 \%$ of them agreed to reprocess household liquid waste, reuse liquid waste for plants and dispose of liquid waste in flowing gutters. Then in terms of behavior, 59.94\% of respondents are very in accordance with the criteria for Community Based Total Sanitation (STBM), namely having sewerage (sewers, IPAL, septic tanks, etc.), utilizing liquid waste for plants and disposing of liquid waste in sewers flows. Therefore, the achievement of the pillar 5 in terms of knowledge and understanding are bad category. Meanwhile, the attitude and behavior aspects are in the very good category. This is an interesting finding where Soerjono Soekanto's theory of awareness level does not always apply sequentially. In this context, a person or group of people can do something well without sufficient knowledge and understanding.

\section{Affecting Factors of Public Awareness Level of the Community-Based Total Sanitation Program (STBM)}

\section{a. Public Knowledge}

Most of the Potrobangsan Village residents already know the appeal and benefits of the STBM Program. Most of them also have independently implemented the behavior of stopping open defecation, washing hands with soap, managing food and beverages properly, and managing waste safely to participate in implementing government programs. However, the disposal of liquid waste, especially household liquid waste, is not optimal yet because there are still many residents who throw the waste directly into the river because they do not know how to properly manage liquid waste. The residents also do not fully understand the impact if the flow of the waste carelessly can pollute the river and cause disease. Residents still have lack of knowledge about the layout between the sewer / tank of liquid waste and infiltration wells, which must be far apart. This is because if this is not done, the well water can be contaminated so that it can become a place for the spread of bacteria and viruses that cause disease. 


\section{b. Social Economic Status}

This research found that most residents already have a toilet in their own house. However, there are still some residents who do not have private toilet due to the small size of the house and the economic conditions that make it impossible to build a toilet in their house. Furthermore, for waste management, there are still a few residents who process it into compost / handicraft products. Only a few residents get economic benefits from the waste management activities, so residents prefer to dispose them directly due to limited time because they have to work and carry out other economic activities.

\section{c. Government Commitment}

The STBM program is implemented through policy support efforts, both written and nonwritten. Potrobangsan Village officer prioritized this program in the planning document. In addition, the local government has also formed a team of health cadres for each resident association (RW), one of which is to foster and educate the public about the importance of environmental sanitation management. The local government has helped to support the pillars of the STBM program, including through the provision of public toilets, septic tanks, communal IPALs, and waste banks. The socialization of the STBM program has been carried out by the village office and resident associations (RT/RW). However, some residents still do not know about the program because not all resident associations are active in giving appeals to their residents. Beside that, in pillar 2 (hanswashing with soap) community members also received information environmental sanitation management from the mass media, especially with the current Covid-19 pandemic conditions.

\section{d. Program Monitoring}

Based this research results, it can be seen that the implementation of monitoring and evaluation carried out by the local government is still not optimal. In addition, strict supervision in the form of warnings and other punishments has not been carried out by the local government so that there are still residents who have not followed the procedures and rules in the STBM Program. The residents hope that the local government not only conduct socialization, but also need to provide examples of direct practice and assistance so that the community can be independent in managing their environmental sanitation. In Potrobangsan Village there is a waste bank, but not all of them are maximized due to lack of resident participation. The local government should not only carry out a waste bank creation program, but must also continue to carry out sustainability programs, especially developing human resources so that the utilization of the waste bank creation can be fully felt by local residents. 


\section{Conclusion}

The level of public awareness of the Community-Based Total Sanitation (STBM) program in Potrobangsan Village from the achievements of the pillars of Stop Open Defecation, Washing Hands with Soap, Management of Drinking Water and Household Food, Safeguarding Household Waste and Safeguarding Household Liquid Waste are in the category good enough to very good except from the perspective of understanding the safety of household liquid waste which is in the bad category. But what is unique about the attitude and behavior of Household Liquid Waste Safeguards has been in the very good category. This proves that the level of understanding is not always directly proportional to attitudes and behavior. In addition, other findings from this study are factors that influence the level of community awareness of the Community-Based Total Sanitation (STBM) program in Potrobangsan Village, including knowledge, social and economic levels of the community, government commitment and program monitoring. Based on previous research, there are the same obstacles in the Community-Based Total Sanitation (STBM) program, namely the economic conditions of the community and program monitoring. Based on the research conducted, the authors provide some input for the level of public awareness of the Community-Based Total Sanitation (STBM) program. First, the aspect of knowledge and understanding related to liquid waste management is the lowest part so that it needs to be improved by providing education through various methods and activities. Second, it is necessary to monitor areas that have not had good sanitation as well as monitoring of areas that are already good whether they consistently apply the STBM pillar. Third, it is necessary to provide social assistance for people who are less well off financially to build water channels in accordance with the STBM provisions.

\section{References}

[1] Ayuningtyas, Dumilah. Kebijakan Kesehatan: Prinsip dan Praktik. Jakarta: Rajawali Pers; 2014.

[2] Dye, Thomas R. Understanding Public Policy (14th edition). Pearson Education, Inc.; 2013.

[3] Ikhtiar, Muhammad. Pengantar Kesehatan Lingkungan. Makasar: CV. Social Politic Genius (SIGn); 2017.

[4] Maramis, W.F. Ilmu Kedokteran Jiwa. Surabaya: Elangga University Press: 1999.

[5] Notoatmodjo, S., Pengantar Kesehatan Masyarakat. Rineka Cipta. Bandung: 2003.

[6] Proverawati A., Rahmawati E., Perilaku Hidup Bersih Dan Sehat (Phbs). Yogyakarta: Nuha Medika; 2012.

[7] Soekanto, Soerjono. Kesadaran Hukum dan Kepatuhan Hukum, Edisi Pertama, Jakarta :Rajawali; 1982.

[8] Smith, Kevin B. dan Christopher W. Larimer. The Public Policy Theory Primer. Philadelphia: Westview Press; 2009.

[9] Antara Jateng. 2019. Wujudkan sanitasi bersih dan sehat, ini yang dilakukan Pemkot Magelang . Available from https://jateng.antaranews.com/berita/266542/wujudkansanitasi-bersih-dan-sehat-ini-yang-dilakukan-pemkot-magelang

[10] PDAM Kota Magelang. Tingkatkan layanan air bersih, PDAM Kota Magelang didukung Amerika-Swiss. $2019 . \quad$ Available from https://pdamkotamagelang.com/2019/07/02/tingkatkan-layanan-air-bersih-pdam-kotamagelang-didukung-amerika-swiss/ 
[11] Pemerintah Kota Magelang. Wakil Walikota : Sistem Sanitasi Dibangun Dengan Baik. 2019. Available from http://www.magelangkota.go.id/home/detail/021019rudi2/wakilwalikota---sistem-sanitasi-dibangun-dengan-baik

[12] Sekretariat Bappeda Gunung Kidul. Memperkuat Sanitasi di Masa Pandemi Covid 19. 2020. Available from http://bappeda.gunungkidulkab.go.id/memperkuat-sanitasi-dimasa-pandemi-covid-19/

[13] USAID. Tangki Septik Komunal, Opsi untuk Daerah Kecil dan Padat Penduduk. 2019. Available from https://www.iuwashplus.or.id/arsip/4987 